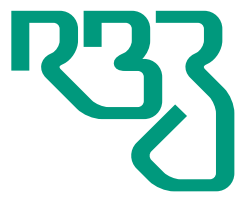

Revista

Brasileira de

Zootecnia

Brazilian Journal of Animal Science

ISSN 1806-9290

www.rbz.org.br

\title{
Can the strategies for endoparasite control affect the productivity of lamb production systems on pastures?
}

\author{
Maria Angela Machado Fernandes ${ }^{1}$ iD, Jordana Andrioli Salgado ${ }^{2}$ (iD), \\ Mylena Taborda Piquera Peres ${ }^{3}$ iD, Karla Francisca Duarte Campos ${ }^{3}$ iD, \\ Marcelo Beltrão Molento $^{4}$ (iD), Alda Lúcia Gomes Monteiro ${ }^{5^{*}}$ iD \\ ${ }^{1}$ Universidade Federal do Paraná, Programa de Pós-Graduação em Ciências Veterinárias, \\ Curitiba, PR, Brasil. \\ ${ }^{2}$ Pontifícia Universidade Católica do Paraná, Programa de Ciência Animal, Curitiba, \\ PR, Brasil. \\ ${ }^{3}$ Universidade Federal do Paraná, Programa de Pós-Graduação em Zootecnia, Curitiba, \\ PR, Brasil. \\ ${ }^{4}$ Universidade Federal do Paraná, Departamento de Medicina Veterinária, Curitiba, \\ PR, Brasil. \\ ${ }^{5}$ Universidade Federal do Paraná, Departamento de Zootecnia, Curitiba, PR, Brasil.
}

*Corresponding author:

aldaufpr@gmail.com

Received: November 15, 2018

Accepted: July 14, 2019

How to cite: Fernandes, M. A. M.; Salgado, J. A.; Peres, M. T. P.; Campos, K. F. D.; Molento, M. B. and Monteiro, A. L. G. 2019. Can the strategies for endoparasite control affect the productivity of lamb production systems on pastures? Revista Brasileira de Zootecnia 48:e20180270. https://doi.org/10.1590/rbz4820180270

Copyright: This is an open access article distributed under the terms of the

Creative Commons Attribution License (http://creativecommons.org/licenses/by/4.0/) which permits unrestricted use, distribution, and reproduction in any medium, provided the original work is properly cited.

\begin{abstract}
The objective of this study was to evaluate the productivity and carcass traits of unweaned Suffolk lambs finished on pasture and subjected to three strategies for endoparasite control: prophylactic treatment of all animals every 28 days; treatment of animals with a cut off number of nematode fecal egg count (FEC) $\geq 700$; and treatment of animals using the FAMACHA scores $\geq 3$. Average daily weight gain (ADG) and FEC were evaluated every 14 days for 112 days. Body condition scores and carcass characteristics were assessed before and after slaughter, respectively. Animal productivity was calculated based on animal stocking rate, ADG, and weight variation per area. Animal productivity, pasture, and carcass characteristics did not differ among strategies of parasite control. Parasite control strategies did not affect the productivity of lambs on pasture or carcass characteristics. Thus, the use of selective treatments can be considered advantageous due to decreased selection pressure for resistant parasite populations and lower use of drugs.
\end{abstract}

Keywords: animal production, carcass dressing, FAMACHA, fecal egg count, Haemonchus contortus

\section{Introduction}

In sheep production, the main objective is undoubtedly the economic production, maintaining high welfare indicators. To achieve this, biotic and abiotics aspects (i.e. nutrition and health programs) have an important impact on animal yield (Demirhan, 2019). Finishing lambs on pasture is challenging due to the high rate of nematode infections (Molento et al., 2016). Favorable conditions (temperature, pluviosity, and humidity) are essential for parasite viability on pasture (Bowman et al., 2003), and the climate in tropical and subtropical regions is favorable for Haemonchus contortus, the most prevalent and pathogenic nematode of small ruminants (Geary, 2016). Furthermore, imported breeds with high nutritional requirements and sensibility to gastrointestinal nematodes are used in Brazil to improve productivity indexes (Amarante et al., 2004).

Pasture-based sheep production is more challenging to young animals due to their high susceptibility to parasite infections (Greer, 2009), since nutritional management and parasite control are crucial for 
their performance (Salgado et al., 2018). The immunity against parasites increases at different levels with age (McRae et al., 2015), and the strategy for parasite control must contribute to achieving the maximum productivity of animals under parasite challenge.

Management practices are used to monitor, control, and reduce nematode infections in sheep production. Traditionally, the strategies to control gastrointestinal nematodes are based on the use of anthelmintics at fixed intervals with high rotational rates (González-Garduño et al., 2014). The consequence of this is the strong selection pressure for homozygous resistant parasites and the loss of heterozygosity to the local populations (Fortes and Molento, 2013). Therefore, Salgado and Santos (2016) reported one of the highest anthelmintic resistance to all chemical groups in Brazil, and improved strategies for parasite control are needed. In addition, the excessive and indiscriminate use of veterinary drugs might result in residues in meat, milk, and the environment, which is relevant to the current production context (Fernandes et al., 2017).

The search for selective strategies for endoparasite control in lamb production systems has aimed to improve animal productivity through the rational use of parasiticides (Bentounsi et al., 2012; Busin et al., 2014). Along this way, the main selective strategies used in Brazil are based on the fecal egg count (Ueno and Gonçalves, 1998) and the FAMACHA (FMC) guide (Van Wyk and Bath, 2002; Molento et al., 2004). The objective of this study was to evaluate the productivity and carcass traits of unweaned lambs finished on summer pastures and subjected to distinct strategies of endoparasite control.

\section{Material and Methods}

The experiment was carried out between January and May 2012 in Pinhais, Paraná, Southern Brazil $\left(25^{\circ} 24^{\prime} \mathrm{S}, 4^{\circ} 07^{\prime} \mathrm{E}\right.$, and $900 \mathrm{~m}$ asl). Research on animals was conducted according to the institutional Committee of Animal Ethics (case no. 055/2011). According to the Köppen-Geiger climate classification (Peel, 2007), the climate is $\mathrm{Cfb}$ (humid subtropical), with the average annual rainfall from 1400 to $1600 \mathrm{~mm}$ and mean temperature of $17^{\circ} \mathrm{C}$ (SIMEPAR, 2012).

Lambs were weighed right after birth, identified and kept with the ewes in a suspended barn. The lambs had access to Tifton-85 (Cynodon spp.) pastures when reached three weeks of age, together with the ewes, to promote their adaptation to electric fences. Water was offered ad libitum. Lambs were kept with their mothers throughout the experimental period (112 days). The initial mean age ( \pm standard error) and body weight (BW) were, respectively, $42( \pm 3)$ days and $18.9( \pm 1.3) \mathrm{kg}$ for the lambs, and 3.5 years and $59.6( \pm 6.7) \mathrm{kg}$ for the ewes.

Forty-two Suffolk lambs (20 non-castrated males and 22 females; $n=14$ per treatment) were evaluated in randomized blocks with three treatments (strategies for endoparasite control) and three blocks. The animals were distributed in blocks according to sex (non-castrated male or female) and type of birth (single or twin). Blocks 1, 2, and 3 consisted, respectively, of females from single birth, males from single birth, and males and females from twin birth (Figure 1).

\begin{tabular}{|c|c|c|c|c|c|c|c|c|}
\hline \multicolumn{2}{|c|}{ Block 1 - females from single birth } & \multicolumn{3}{|c|}{ Block 2 - males from single birth } & \multicolumn{2}{|c|}{ Block 3 - males and females from twin birth } \\
\hline PRO & EPG & FMC & PRO & EPG & FMC & PRO & EPG & FMC \\
Five lambs & Five lambs & Five lambs & Five lambs & Five lambs & Five lambs & Four lambs & Four lambs & Four lambs \\
\hline
\end{tabular}

${ }^{1}$ PRO: prophylactic treatment of all animals; EPG: treatment with number of eggs per gram of feces (FEC $\geq 700$ ); FMC: treatment based on FAMACHA scores.

Each part inside the block represents a paddock.

Figure 1 - Experimental design for lambs finished on summer pasture and subjected to three strategies ${ }^{1}$ for endoparasite control. 
The strategies used for endoparasite control were: PRO - prophylactic treatment of all animals every 28 days; EPG - treatment of animals based on the cut off for fecal egg count ( $\geq 700)$; and FMC treatment with FMC scores $\geq 3$. Fecal samples were collected from the rectum of the animals every 14 days and the parasite eggs from the Strongylida order were counted using the modified Gordon and Whitlock (1939) technique. Fecal egg counts (FEC) were performed every 14 days in all lambs, but it was used as treatment criteria only for the EPG group. In all control strategies, the lambs remained in the experiment until slaughter.

The anthelmintic combination of moxidectin $1 \%$ at a dose of $200 \mathrm{mg} / \mathrm{kg}$ body weight (BW) (Cydectin, Fort Dodge, Iowa, USA) and nitroxinil 34\% at a dose of $34 \mathrm{mg} / \mathrm{kg}$ BW (Dovenix Supra, Merial, SP, Brazil) both given intramuscularly was used. The combination had an overall efficacy of $89 \%$. All ewes were treated at the beginning of the experiment and monitored every 14 days using the FMC guide. No lamb received anthelmintic treatment before starting the experimental period. The treatment was applied at the weighing days, and the dose was calculated based on BW. The FMC guide was used to evaluate the color of the conjunctiva of the animals to a decreasing 5-to-1 anemia score (Van Wyk and Bath, 2002). To use the method, the prevalence of Haemonchus spp. was assessed through a pool coproculture and the infective larvae (L3) were identified according to Van Wyk and Mayhew (2013).

The experiment was conducted in a 1.8 ha area divided into nine Tifton- 85 paddocks ( 0.2 ha each). The stocking rate was adjusted every 14 days based on the mean height $(15 \mathrm{~cm})$ of the pasture, calculated through 68 measurements per paddock using a sward stick (Barthram, 1986).

Forage mass and morphological composition were assessed by collecting three forage samples in each plot using an iron circle with $0.1 \mathrm{~m}^{2}$ of area. All fractions were oven-dried to a constant weight at $65^{\circ} \mathrm{C}$ (approx. $48 \mathrm{~h}$ ) and weighed on a 0.01-g precision scale (ME2002T, Mettler; Toledo, SP, Brazil). The dry matter (DM) of each fraction was used to calculate forage mass (FM), leaf blade mass (LB), sheath and stem mass (SS), and dead material mass (DD), all of them expressed in $\mathrm{kg} \mathrm{DM} / \mathrm{ha}$. The leaf-to-stem ratio was calculated by dividing LB dry mass by the SS dry mass.

To calculate the ADG, lambs were weighed every 14 days after a 16-h solid fasting until slaughter. Lambs were slaughtered with pre-set weight of $30 \mathrm{~kg}$, or at the end of the experiment, for those that did not reach this weight. The recommended anthelmintic withdrawal period of 28 days was respected. Parasitological monitoring was performed until April 5th, when the last application of anthelmintic was done. Animal productivity assessments were conducted until May 3rd and 5th, at the end of the trial (112 days). Before slaughter, lambs were weighed and had their body condition score (BSC) based on a five-point scale ( 1 = very thin, 5 = very fat) with 0.5 intervals (Russel et al., 1969).

Lambs were slaughtered by stunning electronarcosis (220 V for $8 \mathrm{~s}$ ), followed immediately by exsanguination by severing the jugular veins and carotid arteries. After skinning and evisceration, hot carcass weight (HCW) was recorded. The carcasses were chilled at $5{ }^{\circ} \mathrm{C}$ for $24 \mathrm{~h}$, and cold carcass weight (CCW) was also recorded. Hot carcass yield was calculated as: $\mathrm{HCY}=\mathrm{HCW} / \mathrm{SW} \times 100$, while cold carcass yield was calculated as: $\mathrm{CCY}=\mathrm{CCW} / \mathrm{SW} \times 100$, and carcass cooling loss as: $\mathrm{CL}=(\mathrm{HCW}-$ $\mathrm{CCW}) / \mathrm{HCW} \times 100$. After chilled, the carcasses were dissected between the last thoracic and the first lumbar vertebras, and backfat thickness (BT) was measured with a digital caliper.

Animal productivity was estimated based on the weight gain of lambs per area. The calculation was based on multiplying the ADG of each lamb by the mean stocking rate (lambs/ha), which in turn was a function of the average body weights of lambs $(25 \mathrm{~kg})$ and ewes $(65 \mathrm{~kg})$.

Pasture and animal productivity data were subjected to normality test to a variance analysis (ANOVA) using a general linear model (Proc GLM) of SAS (Statistical Analysis System, version 9.0) in a randomized complete block design, according to:

$$
Y i j=\mu+\tau i+\beta j+\varepsilon i j
$$

in which Yij is the dependent variable, $\mu$ is the overall mean, $\tau$ i is the fixed effect of treatment $i$ (strategies for endoparasite control), $\beta \mathrm{j}$ is the effect of randomized blocks $j$, and $\varepsilon i j$ is the residual error. 
A Tukey mean test was used when significance was detected $(\mathrm{P}<0.05)$. Data related to the fecal egg counts (FEC), the proportion (\%) of drenched lambs per evaluation, and the proportion (\%) of animals that received between one and six anthelmintic doses per treatment were described and presented graphically.

\section{Results}

Pasture conditions were homogeneous for the three strategies of endoparasite control $(\mathrm{P}>0.05)$ (Table 1$)$.

Animal productivity, stocking rate, body weight gain per area, and carcasses characteristics were not affected $(\mathrm{P}>0.05)$ by any strategy of parasite control (Table 2 ).

The average daily weight gain of lambs was $132.6( \pm 15.3) \mathrm{g} / \mathrm{d}$, and the mean stocking rate was 19.3 $( \pm 1.0)$ lambs/ha. So, the weight gain per area was $487.4( \pm 33.2) \mathrm{kg} \mathrm{BW} / \mathrm{ha}$, considering 112 days of experimental trial.

The genera and the prevalence of nematodes were evaluated, and Haemonchus sp. was the most prevalent genus during the experimental period, from January to May (Table 3).

Table 1 - Mean and standard errors of height, forage mass (FM), leaf blade (LB), sheath and stem (SS), dead material (DD), and leaf:stem ratio (L:S) of Tifton-85 pasture in the three strategies for endoparasite control

\begin{tabular}{lcccc}
\hline & \multicolumn{3}{c}{ Strategy $^{1}$} & \multirow{2}{*}{ P } \\
\cline { 2 - 4 } & PRO & EPG & FMC & 0.3892 \\
Height (cm) & $16.0 \pm 1.2$ & $16.8 \pm 1.3$ & $17.6 \pm 1.3$ & 0.4904 \\
FM (kg DM/ha) & $3,670.9 \pm 303.5$ & $3,957.4 \pm 316.9$ & $4,079.9 \pm 279.7$ & 0.3920 \\
LB (kg DM/ha) & $899.3 \pm 135.9$ & $751.1 \pm 105.8$ & $802.5 \pm 107.4$ & 0.9780 \\
SS (kg DM/ha) & $1,279.9 \pm 199.6$ & $1,441.3 \pm 173.9$ & $1,540 \pm 123.3$ & 0.3027 \\
DD (kg DM/ha) & $1,230.4 \pm 197.6$ & $1,280.71 \pm 180.2$ & $1,435.9 \pm 213.6$ & 0.4632 \\
L:S & $0.88 \pm 0.11$ & $0.61 \pm 0.07$ & $0.60 \pm 0.07$ & 0.07 \\
\hline
\end{tabular}

${ }^{1}$ PRO: prophylactic treatment of all animals; EPG: treatment with number of eggs per gram of feces (FEC $\geq 700$ ); FMC: treatment based on FAMACHA scores.

Table 2 - Mean and standard errors of animal performance and carcass characteristics of lambs finished on Tifton-85 pastures and subjected to three strategies for endoparasite control

\begin{tabular}{|c|c|c|c|c|}
\hline & \multicolumn{3}{|c|}{ Strategy $^{1}$} & \multirow{2}{*}{$\mathrm{P}$} \\
\hline & PRO & EPG & FMC & \\
\hline Slaughter weight (kg) & $30.9 \pm 1.3$ & $29.7 \pm 1.4$ & $28.4 \pm 1.2$ & 0.092 \\
\hline Mean daily weight gain (g/day) & $138 \pm 13$ & $142 \pm 20$ & $118 \pm 13$ & 0.128 \\
\hline Slaughter condition score & $2.8 \pm 0.1$ & $2.6 \pm 0.1$ & $2.6 \pm 0.1$ & 0.859 \\
\hline Backfat thickness (mm) & $3.16 \pm 0.52$ & $2.66 \pm 0.4$ & $2.27 \pm 0.4$ & 0.304 \\
\hline Hot carcass yield (\%) & $43.5 \pm 1.2$ & $44.7 \pm 1.3$ & $42.7 \pm 1.2$ & 0.068 \\
\hline Cold carcass yield (\%) & $42.5 \pm 1.2$ & $43.5 \pm 1.3$ & $41.6 \pm 1.2$ & 0.074 \\
\hline Cooling loss $(\%)$ & $2.3 \pm 0.1$ & $2.3 \pm 0.1$ & $2.5 \pm 0.1$ & 0.217 \\
\hline
\end{tabular}

${ }^{1}$ PRO: prophylactic treatment of all animals; EPG: treatment with number of eggs per gram of feces (FEC $\geq 700$ ); FMC: treatment with FAMACHA scores.

Table 3 - Prevalence of the nematodes (\%) identified in coproculture of lamb feces, subjected to three strategies ${ }^{1}$ for endoparasite control

\begin{tabular}{lcccccc}
\hline Genera (spp.) & January & February & March & April & May & Average \\
\hline Haemonchus & 74.6 & 66.0 & 59.6 & 35.0 & 72.2 & $61.5 \%$ \\
Teladorsagia & 13.0 & 19.3 & 27.0 & 33.0 & 15.5 & $21.5 \%$ \\
Cooperia & 8.7 & 6.6 & 5.1 & 8.0 & 2.3 & $6.1 \%$ \\
Trichostrongylus & 3.7 & 8.1 & 8.3 & 24.0 & 10.0 & $10.9 \%$ \\
\hline
\end{tabular}

${ }^{1}$ Prophylactic treatment of all animals; treatment with number of eggs per gram of feces (FEC>700); treatment with FAMACHA scores. 
There was no significant difference $(\mathrm{P}>0.05)$ in the mean number of anthelmintic doses among the strategies (PRO - 3.0; FMC - 2.4; EPG - 2.7), because the animals were slaughtered as they reached the pre-set weight (Table 2). This caused different numbers of anthelmintic applications in the PRO group. Thus, lambs slaughtered earlier, received two $(30.8 \%)$ or three $(38.5 \%)$ anthelmintic doses, while those that remained until the last evaluation (30.8\%) received four doses. Nevertheless, $100 \%$ of PRO animals received anthelmintics every 28 days (Figure 2). The proportion of lambs that received between zero and six anthelmintic doses (Figure 3) shows that the variation in the number of doses was related to the control strategy and the number of days for lambs to reach the slaughter weight.

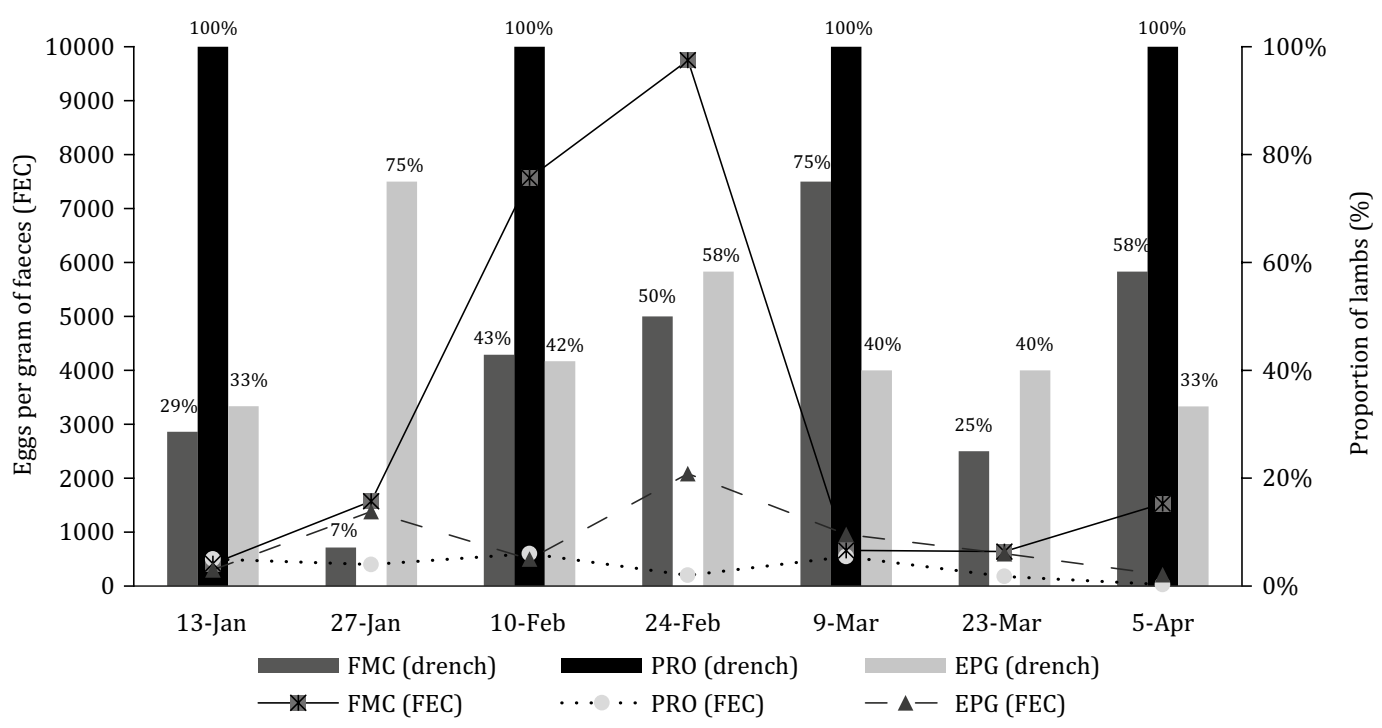

${ }^{1}$ The proportion (\%) was calculated considering the total number of lambs in each date per treatment.

${ }^{2}$ PRO: prophylactic treatment of all animals; EPG: treatment with number of eggs per gram of feces (FEC $\geq 700$ ); FMC: treatment with FAMACHA. Arrows indicate the dates of PRO applications.

Figure 2 - Number of fecal eggs per gram of feces (FEC; lines) and proportion ${ }^{1}$ of drenched lambs (\%; bars) finished on summer pasture and subjected to three strategies ${ }^{2}$ for endoparasite control.

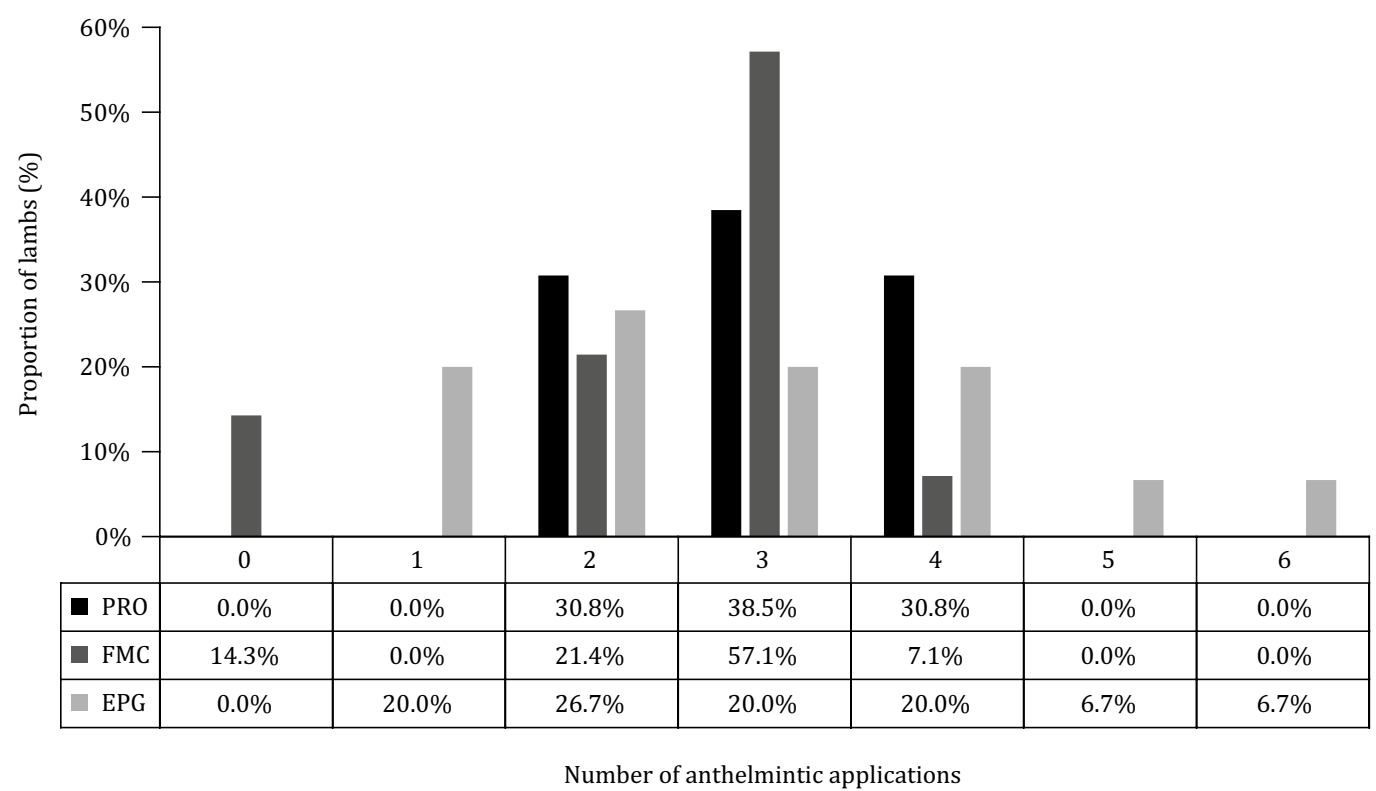

PRO: prophylactic treatment of all animals; EPG: treatment with number of eggs per gram of feces (FEC $\geq 700$ ); FMC: treatment with FAMACHA.

Figure 3 - Proportion of lambs (\%) finished on summer pasture that received between zero and six anthelmintic applications, subjected to strategies ${ }^{1}$ for endoparasite control. 
The FEC variation for each strategy (Figure 2) shows that the lambs subjected to either PRO or EPG strategies presented from 0 to 2000 FEC. The largest variation was observed in lambs subjected to FMC, with an average counting of 10,000 in February, reflecting the H. contortus season in South of Brazil. The rainfall during the experimental period was $570 \mathrm{~mm}$, and the temperature ranged between 12 and $25^{\circ} \mathrm{C}$.

\section{Discussion}

We determined that performance and animal productivity were not affected by the studied parasite control strategies. The animals in the present study were raised under similar feed conditions, which could have imposed a central influence in productivity and pasture characteristics. The forage supply followed the recommended forage height and mass for ewes with growing lambs, allowing the maximum feed intake (Mezzalira et al., 2014). This recommendation aimed to ensure the best performance of animals even under different endoparasite challenge. The production systems can influence parasitic infection in lambs, such as weaning of lambs or feed supplementation, and can be relevant to the response to parasites (Salgado et al., 2018). Depner et al. (2007) reported no significant effect of FMC and prophylactic strategies on performance of Ile de France lambs between four and eight months old in Rio Grande do Sul, Brazil. Arece-García et al. (2016) also reported no significant effect of FMC and prophylactic strategies on milk production in sheep. Both studies showed that a more frequent use of veterinary drugs did not necessarily guarantee better performance, as has been shown in studies comparing selective and prophylactic suppressive treatments (Kenyon et al., 2009; Jackson, 2017).

Lambs subjected to FMC strategy had the greatest variation in FEC but did not differ from the other groups regarding performance $(\mathrm{ADG}=118 \mathrm{~g}$ /day). Our results showed that both FMC and EPG strategies were effective mainly because of the early identification of the infected animals with similar performance if compared with the PRO strategy. However, EPG strategy requires equipment, trained professionals, and time for sample processing until a decision on anthelmintic application can be made. There is also a possibility of the density-dependent effect, as animals with a small parasite load may eliminate a large number of eggs, being incorrectly treated.

As expected, the number of anthelmintic applications varied among the selective strategies, since there are different degrees of susceptibility to endoparasites. According to Saddiqi et al. (2011), the ability of a sheep to acquire immunity and express resistance varies substantially among and within breeds. Besides, given that there is some heritability of resistance to gastrointestinal parasites, the FMC scores indicates that selection process is possible in breeding programs (Berton et al., 2017). Selective strategies are based on phenotypic parameters that are used to select animals more resilient to endoparasites, which is not possible when a prophylactic strategy is applied to the entire flock (Molento et al., 2004).

However, our data suggest that selective strategies should be used together with other criteria for endoparasite control. For example, there was a prevalence of Haemonchus sp. in most evaluations, apart from April, when Trichostrongylus sp. and Teladorsagia sp. were predominant. This variation did not affect animal performance in the present study, but the use of other criteria such as FEC or clinical signs (i.e., diarrhea) is recommended. Cintra et al. (2018) reported a low sensitivity of growing lambs to FMC and recommended that it should not be used alone to evaluate young animals. It is known that the small ocular area of young animals makes the FMC evaluations more difficult (Fernandes et al., 2015).

The FEC variation (from 0 to 10,000) also indicates that EPG monitoring in lambs should be more frequent in the summer due to the continuous $\mathrm{H}$. contortus infection and favorable climate conditions. In the present study, the high EPG $(>2,000)$ indicates a massive mixed infection (Ueno and Gonçalves, 1998). The breeds selected for higher weight gain and early finishing, such as Suffolk and other meat breeds, are more susceptible to parasitic infections when compared with native breeds (Santa Inês and Morada Nova) (Amarante et al., 2004). Our animals were between 42 and 140 days of age and showed 
little tolerance against parasites (Greer et al., 2009). Pasture-based sheep production favors parasite infections that could lead to death, especially for early weaned lambs (45-65 days of age). Ribeiro et al. (2009) reported an average mortality rate of $20 \%$ caused by endoparasite infections in lambs raised on pasture in subtropical regions.

Neither performance, slaughter weight, BCS, nor carcass characteristics differed among the animals in any parasite control strategies. The average BT of $2.4 \mathrm{~mm}$ was classified as moderate (Johnson et al., $2005)$ and could have influenced the average cooling loss (2.4\%), which was lower than the maximum acceptable levels (3-4\%) (Almeida Júnior et al., 2004). In contrast, the average BCS (2.7) was lower than the recommended (3-3.5) (Russel et al., 1969). It is known that the performance of lambs could be influenced by feed supplementation, since the nutritional supply plays a crucial role in the control of parasites in ruminants (Hoste et al., 2016). Silva et al. (2012), Poli et al. (2008), and Ribeiro et al. (2009) assessed the performance of suckling lambs finished on pasture and reported an ADG of 130, 281, and $303 \mathrm{~g} /$ day, respectively.

Although there was no difference $(\mathrm{P}<0.05)$ in the mean number of anthelmintic doses, several studies reported a reduction in the use of anthelmintic when the decision was based on FEC (Leathwick et al., 2006; Cringoli et al., 2009; Gaba et al., 2010) or FMC (Depner et al., 2007; Molento et al., 2009). Thus, we consider that the production system, number of animals in the flock, season, and efficacy of the drug must be considered before choosing the strategy to be applied, as they can influence production costs, parasite challenge, selection pressure for resistant parasites, and veterinary drug residues in both meat and the environment.

The FMC strategy resulted in the highest number of lambs with no anthelmintic use (14.3\%), when compared with the other two strategies. This is extremely important, as we need to keep part of parasite populations in refugia to dilute drug selection and maintain anthelmintic efficacy (Jackson et al., 2017). Kenyon et al. (2013) reported that a monthly prophylactic treatment decreased the efficacy of ivermectin compared with other three strategies. According to Molento et al. (2004), the good productivity observed in sheep under prophylactic treatments could lead to a false impression of the efficacy of a prophylactic method. However, the higher the frequency and the shorter the interval between applications, the greater the selection pressure of parasites to most of anthelmintic classes (Papadopoulos et al., 2013). These suppressive strategies have a clear consequence of reducing the refugia population. Thus, the strategy for endoparasite control must be chosen carefully even for short-period finishing systems, since it may affect both the animal performance and future parasite population for resistance.

In some cases, more animals were treated in the FMC group than in the EPG (Figure 2), reaffirming that the degree of anemia should be used along other clinical and performance indicators for a more appropriate treatment criteria for lambs (Cintra et al., 2018). Besides, more EPG animals (6.7\%; Figure 3) received between five and six doses, but probably some animals would not need as much treatment if FMC was used in combination. Thus, although it is evident the importance of incorporating selective treatments, an integrated parasitic control program is recommended for lambs using tools such as FEC, FMC, or even the performance of animals (Molento et al., 2004; McBean et al., 2016).

\section{Conclusions}

The three strategies for endoparasite control do not affect the productivity and carcass traits of unweaned lambs finished on pasture and the selective strategies are directly beneficial over herd treatment. The FAMACHA guide and treatment of animals based on the cut off for fecal egg count can reduce the selection pressure for resistant parasite populations, as treatments are not given to the entire herd. Associated to that, the diagnostic-based treatments can also give indirect advantages to sustainable farming systems with less drug residues in the environment.

R. Bras. Zootec., 48:e20180270, 2019 


\section{Conflict of Interest}

The authors declare no conflict of interest.

\section{Author Contributions}

Conceptualization: M.B. Molento and A.L.G. Monteiro. Fundingacquisition: A.L.G. Monteiro. Investigation: M.A.M. Fernandes, J.A. Salgado, M.T.P. Peres, M.B. Molento and A.L.G. Monteiro. Methodology: M.A.M. Fernandes, J.A. Salgado, M.T.P. Peres, M.B. Molento and A.L.G. Monteiro. Project administration: A.L.G. Monteiro. Resources: A.L.G. Monteiro. Supervision: A.L.G. Monteiro. Writing-original draft: M.A.M. Fernandes, J.A. Salgado, K.F.D. Campos, M.B. Molento and A.L.G. Monteiro. Writing-review \& editing: M.A.M. Fernandes, J.A. Salgado, M.B. Molento and A.L.G. Monteiro.

\section{Acknowledgments}

The authors gratefully acknowledge the Conselho Nacional de Desenvolvimento Científico e Tecnológico (CNPq) for the financial support and research fellowships. A. L. G. M. is member of the MARCARNE network, funded by CYTED (ref. 116RT0503).

\section{References}

Almeida Júnior, G. A.; Costa, C.; Monteiro, A. L. G.; Garcia, C. A.; Munari, D. P. and Neres, M. A. 2004. Desempenho, características de carcaça e resultado econômico de cordeiros criados em creep feeding com silagem de grãos úmidos de milho. Revista Brasileira de Zootecnia 33:1048-1059. https://doi.org/10.1590/S1516-35982004000400025

Amarante, A. F. T.; Bricarello, P. A.; Rocha, R. A. and Genari, S. M. 2004. Resistance of Santa Ines, Suffolk and Ile de France lambs to naturally acquired gastrointestinal nematode infections. Veterinary Parasitology 120:91-106. https://doi.org/10.1016/j.vetpar.2003.12.004

Arece-García, J.; López-Leyva, Y.; González-Garduño, R.; Torres-Hernandez, G.; Rojo-Rubio, R. and Marie-Magdeleine, C. 2016. Effect of selective anthelmintic treatments on health and production parameters in Pelibuey ewes during lactation. Tropical Animal Health and Production 48:283-287. https://doi.org/10.1007/s11250-015-0947-8

Barthram, G. T. 1986. Experimental techniques: the HFRO sward stick. Hill Farming Research Organization, Penicuik. p.29-30.

Bentounsi, B.; Meradi, S. and Cabare J. 2012. Towards finding effective indicators (diarrhoea and anaemia scores and weight gains) for the implementation of targeted selective treatment against the gastro-intestinal nematodes in lambs in a steppic environment. Veterinary Parasitology 187:275-279. https://doi.org/10.1016/j.vetpar.2011.12.024

Berton, M. P.; Silva, R. M. O.; Peripolli, E.; Stafuzza, N. B.; Martin, J. F.; Álvarez, M. S.; Gavinã, B. V.; Toro, M. A.; Banchero, G.; Oliveira, P. S.; Eler, J. P.; Baldi, F. and Ferraz, J. B. S. 2017. Genomic regions and pathways associated with gastrointestinal parasites resistance in Santa Inês breed adapted to tropical climate. Journal of Animal Science and Biotechnology 8:73. https://doi.org/10.1186/s40104-017-0190-4

Bowman, D. D.; Georgi, J. R. and Lynn R. C. 2003. Georgis' parasitology for veterinarians. Saunders Publishing Company, St. Louis, Missouri.

Busin, V.; Kenyon, F.; Parkin, T.; McBean, D.; Laing, N.; Sargison. N. D. and Ellis, K. 2014. Production impact of a targeted selective treatment system based on liveweight gain in a commercial flock. The Veterinary Journal 200:248-252. https://doi.org/10.1016/j.tvjl.2014.02.012

Cintra, M. C. R.; Ollhoff, R. D. and Sotomaior, C. S. 2018. Sensitivity and specificity of the FAMACHA system in growing lambs. Veterinary Parasitology 251:106-111. https://doi.org/10.1016/j.vetpar.2018.01.005

Cringoli, C.; Rinaldi, L.; Veneziano, V.; Mezzino, L.; Vercruysse, J. and Jackson, F. 2009. Evaluation of targeted selective treatments in sheep in Italy: Effects on faecal worm egg count and milk production in four case studies. Veterinary Parasitology 164:36-43. https://doi.org/10.1016/j.vetpar.2009.04.010

Demirhan, S. A. 2019. Sheep farming business in Uşak city of Turkey: Economic structure, problems and solutions. Saudi Journal of Biological Sciences 26:352-356. https://doi.org/10.1016/j.sjbs.2018.10.004

Depner, R. A.; Gavião, A. A.; Cecim, M.; Rocha, R. and Molento, M. B. 2007. Growth performance in naturally infected lambs under selective treatment with FAMACHA method and preventive treatment. Archives of Veterinary Science 12:32-37.

R. Bras. Zootec., 48:e20180270, 2019 
Fernandes, M. A. M.; Gilaverte, S.; Buzatti, A.; Sprenger, L. K.; Silva, C. J. A.; Peres, M. T. P.; Molento, M. B. and Monteiro, A. L. G. 2015. Método FAMACHA para detectar anemia clínica causada por Haemonchus contortus em cordeiros lactentes e ovelhas em lactação. Pesquisa Veterinária Brasileira 35:525-530. https://doi.org/10.1590/S0100-736X2015000600006

Fernandes, M. A. M.; Gilaverte, S.; Bianchi, M. D.; Silva, C. J. A.; Molento, M. B.; Reyes, F. G. R. and Monteiro, A. L. G. 2017. Moxidectin residues in tissues of lambs submitted to three endoparasite control programs. Research in Veterinary Science 114:406-411. https://doi.org/10.1016/j.rvsc.2017.07.010

Fortes, F. S. and Molento, M. B. 2013. Resistência anti-helmíntica em nematoides gastrintestinais de pequenos ruminantes: avanços e limitações para seu diagnóstico. Pesquisa Veterinária Brasileira 33:1391-1402. https://doi.org/10.1590/ S0100-736X2013001200001

Gaba, S.; Cabaret, J.; Sauvé, C.; Cortet, J. and Silvestre, A. 2010. Experimental and modeling approaches to evaluate different aspects of the efficacy of Targeted Selective Treatment of anthelmintics against sheep parasite nematodes. Veterinary Parasitology 171:254-262. https://doi.org/10.1016/j.vetpar.2010.03.040

Geary, T. G. 2016. Haemonchus contortus: applications in drug discovery. Advances in Parasitology 93:429-463. https://doi.org/10.1016/bs.apar.2016.02.013

González-Garduño, R.; Torres-Acosta, J. F. J. and Chay-Canul, A. J. 2014. Susceptibility of hair sheep ewes to nematode parasitism during pregnancy and lactation in a selective anthelmintic treatment scheme under tropical conditions. Research in Veterinary Science 96:487-492. https://doi.org/10.1016/j.rvsc.2014.03.001

Gordon, H. M. and Whitlock, H. V. 1939. A new technique for counting nematode eggs in sheep faeces. Journal of the Council for Scientific and Industrial Research 12:50-53.

Greer, A. W.; Sedcole, R. J.; Jay, N. P.; McAnulty, R. W.; Green, R. S.; Stankiewicz, M. and Sykes A. R. 2009. Protein supply influences the nutritional penalty associated with the development of immunity in lambs infected with Trichostrongylus colubriformis. Animal 3:437-445. https://doi.org/10.1017/S1751731108003534

Hoste, H.; Torres-Acosta, J. F. J.; Quijada, J.; Chan-Perez, I.; Dakheel, M. M.; Kommurud, D. S.; Mueller-Harvey, I. and Terrill, T. H. 2016. Interactions between nutrition and infections with Haemonchus contortus and related gastrointestinal nematodes in small ruminants. Advances in Parasitology 93:239-351. https://doi.org/10.1016/bs.apar.2016.02.025

Jackson, A.; Ellis, K. A.; McGoldrick, J.; Jonsson, N. N.; Stear, M. J. and Forbes, A. B. 2017. Targeted anthelmintic treatment of parasitic gastroenteritis in first grazing season dairy calves using daily live weight gain as an indicator. Veterinary Parasitology 244:85-90. https://doi.org/10.1016/j.vetpar.2017.07.023

Johnson, P. L.; Purchas, R. W.; McEwan, J. C. and Blair, H. T. 2005. Carcass composition and meat quality differences between pasture-reared ewe and ram lambs. Meat Science 71:383-391. https://doi.org/10.1016/j.meatsci.2005.04.021

Kenyon, F.; Greer, A. W.; Coles, G. C.; Cringoli, G.; Papadopoulus, E.; Cabaret, J.; Berrag, B.; Varady, M.; Van Wyk, J. A.; Thomas, E.; Vercruysse, J. and Jackson, F. 2009. The role of targeted selective treatments in the development of refugia-based approaches to the control of gastrointestinal nematodes of small ruminants. Veterinary Parasitology 164:3-11. https://doi.org/10.1016/j.vetpar.2009.04.015

Kenyon, F.; McBean, D.; Greer, A. W.; Burgess, C. G.; Morrison, A. A.; Bartley, D. J.; Bartley, Y.; Devin, L.; Nath, M. and Jackson, F. 2013. A comparative study of the effects of four treatment regimes on ivermectin efficacy, body weight and pasture contamination in lambs naturally infected with gastrointestinal nematodes in Scotland. International Journal for Parasitology: Drugs and Drug Resistance 3:77-84. https://doi.org/10.1016/j.ijpddr.2013.02.001

Leathwick, D. M.; Waghorn, T. S.; Miller, C. M.; Atkinson, D. S.; Haack, N. A. and Oliver, A. M. 2006. Selective and ondemand drenching of lambs: impact on parasite populations and performance of lambs. New Zealand Veterinary Journal 54:305-312. https://doi.org/10.1080/00480169.2006.36715

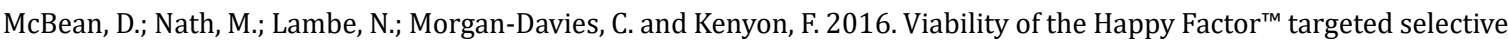
treatment approach on several sheep farms in Scotland. Veterinary Parasitology 218:22-30. https://doi.org/10.1016/j. vetpar.2016.01.008

McRae, K. M.; Stear, M. J.; Good, B. and Keane, O. M. 2015. The host immune response to gastrointestinal nematode infection in sheep. Parasite Immunology 37:605-613. https://doi.org/10.1111/pim.12290

Mezzalira, J. C.; Carvalho, P. C. F.; Fonseca, L.; Bremm, C.; Cangiano, C.; Gonda, H. L. and Laca, E. A. 2014. Behavioural mechanisms of intake rate by heifers grazing swards of contrasting structures. Applied Animal Behaviour Science 153:1-9. https://doi.org/10.1016/j.applanim.2013.12.014

Molento, M. B.; Buzatti, A. and Sprenger, L. K. 2016. Pasture larval count as a supporting method for parasite epidemiology, population dynamic and control in ruminants. Livestock Science 192:48-54. https://doi.org/10.1016/j.livsci.2016.08.013

Molento, M. B.; Tasca, C.; Gallo, A.; Ferreira, M.; Bononi, R. and Stecca, E. 2004. Método Famacha como parâmetro clínico individual de infecção por Haemonchus contortus em pequenos ruminantes. Ciência Rural 34:1139-1145. https://doi.org/10.1590/S0103-84782004000400027

Molento, M. B.; Gavião, A. A.; Depner, R. A. and Pires, C. C. 2009. Frequency of treatment and production performance using the FAMACHA method compared with preventive control in ewes. Veterinary Parasitology 162:314-319. https://doi.org/10.1016/j.vetpar.2009.03.031

R. Bras. Zootec., 48:e20180270, 2019 
Papadopoulos, E.; Gallidis, E.; Ptochos, S. and Fthenakis, C. G. 2013. Evaluation of the FAMACHA@ system for targeted selective anthelmintic treatments for potential use in small ruminants in Greece. Small Ruminant Research 110:124-127. https://doi.org/10.1016/j.smallrumres.2012.11.019

Peel, M. C.; Finlayson, B. L. and McMahon, T. A. 2007. Updated world map of the Köppen-Geiger climate classification. Hydrology and Earth System Sciences 11:1633-1644. https://doi.org/10.5194/hess-11-1633-2007

Poli, C. H. E. C.; Monteiro, A. L. G.; Barros, C. S.; Moraes, A.; Fernandes, M. A. M. and Piazzeta, H. V. L. 2008. Produção de ovinos de corte em quatro sistemas de produção. Revista Brasileira de Zootecnia 37:666-673. https://doi.org/10.1590/ S1516-35982008000400012

Ribeiro, T. M. D.; Monteiro, A. L. G.; Poli, C. H. E. C.; Moraes, A.; Silva, A. L. P. and Barros, C. S. 2009. Características da pastagem de azevém e produtividade de cordeiros em pastejo Revista Brasileira de Zootecnia 38:580-587. https://doi.org/10.1590/S1516-35982009000300025

Russel, A. J. F.; Doney, J. M. and Gunn, R. G. 1969. Subjective assessment of body fat in live sheep. Journal of Agricultural Science 72:451-454. https://doi.org/10.1017/S0021859600024874

Saddiqi, H. A.; Jabbar, A.; Sarwar, M.; Iqbal, Z.; Muhammad, G.; Nisa, M. and Shahzad, A. 2011. Small ruminant resistance against gastrointestinal nematodes: a case of Haemonchus contortus. Parasitology Research 109:1483-1500. https://doi.org/10.1007/s00436-011-2576-0

Salgado, J. A.; Molento, M. B.; Sotomaior, C. S.; Dias, L. T.; Castro, L. L. D.; Faisca, L. D. and Monterio, A. L. G. 2018. Endoparasite and nutritional status of Suffolk lambs in seven production systems. Animal Production Science 58:1667-1676. https://doi.org/10.1071/AN16437

Salgado, J. A. and Santos, C. P. 2016. Overview of anthelmintic resistance of gastrointestinal nematodes of small ruminants in Brazil. Revista Brasileira de Parasitologia Veterinária 251:3-17. https://doi.org/10.1590/S1984-29612016008

Silva, C. J. A.; Monteiro, A. L. G.; Fernandes, S. R.; Poli, C. H. E. C.; Prado, O. R. and Souza, D. F. 2012. Efeito do creep feeding e creep grazing nas características da pastagem de tifton e azevém e no desempenho de ovinos. Ciência Animal Brasileira 13:165-174. https://doi.org/10.5216/cab.v13i2.8812

SIMEPAR - Sistema Meteorológico do Paraná. Available at: <http://www.simepar.br>. Accessed on: July 24, 2012.

Ueno, H. and Gonçalves, P. C. 1998. Manual para diagnóstico das helmintoses de ruminantes. 4.ed. Japan International Cooperation Agency, Tokyo. 166p.

Van Wyk, J. A. and Mayhew, E. 2013. Morphological identification of parasitic nematode infective larvae of small ruminants and cattle: a practical lab guide. Onderstepoort Journal of Veterinary Research 80:539. https://doi.org/10.4102/ojvr v80i1.539

Van Wyk, J. A. and Bath, G. F. 2002. The FAMACHA system for managing haemonchosis in sheep and goats by clinically identifying individual animals for treatment. Veterinary Research 33:509-529. https://doi.org/10.1051/vetres:2002036 